\title{
Preoperative Diagnosis of Acute Appendicitis: Evaluation of Modified Alvarado Scoring System versus Ultrasonography \\ (Original Article)
}

\author{
Authors \\ Dr Jawad Kadhim S. Al-Dhahiry. MD ${ }^{1}$, Dr Hassan Khalil Melek. MD², \\ Dr Tareq Khalid Abduljabbar. MD ${ }^{1}$, Dr Mustafa Farhan Yaly .MB.CH.B ${ }^{2}$ \\ ${ }^{1}$ Dept of Surgery, AL-Karama Teaching Hospital, College of Medicine, Wasit University, Iraq \\ ${ }^{2}$ Dept of Surgery, AL-Zahra' Teaching Hospital, College of Medicine, Wasit University, Iraq \\ Corresponding author \\ Jawad Kadhim S. AL-Dhahiry \\ Assistant Professor \\ Email: jawaddhahiry@gmail.com, Mobile phone: 009647801293684
}

\begin{abstract}
Background: an early preoperative diagnosis of acute appendicitis is ocasionally very challenging. Clinical examination and Ultrasonography (USG) are very useful tools to confirm early preoperative diagnosis of acute appendicitis.

Objective: Evaluation of MASS and USG in preoperative diagnosis of acute appendicitis.

Design and Setting: This is a prospective Cohort study performed in AL-Karama Teaching Hospital/ Medical College / University of Wasit /Iraq.

Patients and Methods: A total of 110 patients complaining of Right Lower Quadrant (RLQ) acute abdominal pain with high suspicion of acute appendicitis, were included_in this study during the period from September 2015 to June 2016.They were preoperatively assessd by Modified Alvarado Scoring system (MASS) and abdominal USG. They were appendectomised. The removed appendicies were histopathologically examined. MASS, USG and histopathologic results were statistically analysied.

Results: They were 67 males $(60.1 \%)$ and 43 females (9.1\%). Mean $\pm S D$ of patients' age was $23.3 \pm 11.9$ years. The post-operative histopathologic examination proved that $98(89 \%)$ out of 110 patients had acute appendicites while the remaining $12(11 \%)$ patients had normal appendices. Sensitivity, specificity, Positive Predictive $(P P V)$, Negative Predictive Value (NPV) and accuracy rate of MASS with cutoff point 6 were : $89 \%, 33 \%, 91 \%, 28 \%$ and $83 \%$ respectively, $P$-value $=0.04$. When MASS with cutoff point 7 , they were $66.3 \%, 12.8 \%, 94.2 \%, 19.5 \%$ and $66 \%$ respectively, $P$-value $=0.03$. Sensitivity, specificity, $P P V, N P V$ and accuracy rate of USG were : $62 \%, 91 \%, 98 \%, 22 \%$ and $65 \%$ respectively, $P$-value $=0.01$.

Conclusion and Clinical Significane: MASS with cutoff point 6 has high sensitivity and accuracy rate .Despite MASS has a slight increase in negative appendectomies but it improves the early diagnosis and treatment preventing complications of delayed diagnosis such as appendiceal perforation. USG gives dependable findings for early diagnosis of acute appendicitis but, it is an operater dependent needing perfect training.
\end{abstract}

Keywords: Diagnosis of Acute Appendicitis, Modified Alvarado Scoring System (MASS), Ultrasonography, 


\section{INTRODUCTION}

Acute appendicitis is the most common surgical disease that needs an emergency surgical intervention worldwide .It's incidence rate is $0.12 \%$. It's incidence rate is highest among teenagers and young adults, but incidence rate of complications of acute appendicitis demonstrates little variation among different age groups ${ }^{[1]}$. If the surgical decision to perform an appendectomy depends only on the patient's symptoms and signs ,this may result in resection of normal appendices (negative appendectomy) in $15 \%$ to $30 \%$ of cases or missing true acute appendicitis leading to an appendiceal perforation ${ }^{[2,3,4]}$.

The main objective of most studies is to reduce both, negative appendectomy rate and complication rate of delayed diagnosis such as appendiceal perforation. A reduction in the negative appendectomy rate must not cause increase in the complication rate ${ }^{[5]}$. Therefore, many diagnostic techniques have been recommended including; clinical scoring systems, USG, CT scans, MRI and laparoscopy ${ }^{[1]}$. World recent diagnostic modalities have demonstrated a reduction in the negative appendectomy rate from $12-29 \%$ to 3-11\%. Graded compression USG is cheap, quick and noninvasive diagnostic technique with an accuracy rate of 71$90 \%$ for diagnosis of acute appendicitis ${ }^{[6]}$. Diagnosis of acute appendicitis can some time be ascertained by clinical examination ${ }^{[7]}$. Absolute and confirmed diagnosis is only possible at surgical exploration and histopathologic examination of the removed appendix ${ }^{[8]}$.

During the last two decades many clinical scoring systems for early diagnosis of acute appendicitis have been introduced and reevaluated by different researchers. These clinical scoring systems include: Lidverg, Fenyo, Christian, Ohman and Alvarado scoring systems ${ }^{[9]}$. Alvarado introduced his scoring system in 1986. This scoring system is composed of, migrating abdominal pain, nausea and /or vomiting, loss of appetite, RLQ abdominal tenderness, rebound tenderness, fever, leukocytosis and a left shift in the leukocyte count. Patients with scores of 7 to 10 will be appendectomised, patients with scores 5 or 6 are advised to be sent for a CT scan to confirm the diagnosis of acute appendicitis ${ }^{[10]}$. Patients with scores $1-4$ are conservatively treated $^{[11]}$.

Despite of using recent diagnostic modalities, diagnosis of acute appendicitis is mostly clinically determined

${ }^{[12]}$. Because white blood cell (WBC) differential count is not usually performed in many hospitals, Kalan et al omitted the left shift of neutrophil count and produced a Modified Alvarado Scoring System (MASS). MASS is a 9 point scoring system helping in increasing the accuracy of preoperative diagnosis of acute appendicitis and decreasing negative appendicectomy rate. MASS with cutoff point 7 was recommended for appendectomy by some researchers ${ }^{[1,10,11,13]}$.

This study evaluated diagnostic values of both; MASS and USG in the preoperative diagnosis of acute appendicitis.

\section{PATIENTS AND METHODS}

Scientific (Ethics) committee of Medical College/Wasit University /Iraq approved this study proposal. During the period from September 2015 to June 2016, one hundred and ten patients presented to Emergency Unit in AL-Krama Teaching Hospital /Medical College /Wasit University /Iraq complaining of RLQ acute abdominal pain with suspicion of acute appendicitis were enrolled in this study. These patients were clinically evaluated using MASS with cutoff point 6, then MASS with cutoff point 7 . Then, they were ultrasonically evaluated. had clinically and ultrasonographically high suspicion of acute appendicitis. All patients were appendectomised by open technique. All removed appendicies were sent for histopathologic examination .MASS, USG and histopathologic results were statistically analysed.

Exclusion criteria were: clinically and ultrasonically proved appendiceal mass, evidence of generalized peritonitis and acute RLQ abdominal pain with pregnancy.

Ultrasonography was performed by specified radiologists, some of them were recently specified .Noncompressible blind loop in right lower abdominal quadrent $\geq 6 \mathrm{~mm}$ in anteroposterior diameter was 
ultrasonographic sign of acute appendicitis ${ }^{[14,15]}$. MASS criteria were fulfilled for each patient. MASS parts were: migrating abdominal pain, loss of appetite, nausea and/or vomiting, RLQ abdominal tenderness, rebound tenderness, fever $\geq 37.5{ }^{0} \mathrm{C}$ and leukocytosis (>10,000 WBCs) ${ }^{[1]} \mathrm{RLQ}$ abdominal tenderness and leukocytosis scored two points for each while other parts scored one point for each (Table. 1.) ${ }^{[1,11]}$. USG, MASS and histopathologic results were statistically analysed using SPSS version 20. All patients scored 1-4 points according to MASS and had ultrasonically negative acute appendicitis, were conservatively treated and discharged home after being improved .No one of them needed appendectomy during follow-up period.

\section{RESULTS AND DISCUSSION}

Table. 2. Shows this study's patients were; 67 (60.1\%) males , 43 (39.1\%) females. The total was 110 patients. Mean \pm SD of patients' age was $23.3 \pm 11.9$ years (5 to 75 years old). Ramachandra. J, et al ${ }^{[11]}$ and Abdelrahim. M,et al ${ }^{[4]}$ reported similar demographic results. This study had no mortality.

\section{I .Histopathologic Results}

Table 3 shows that the histopatholoic examination proved that 98 (89\%) out of 110 patients had acute appendicites while the remaining $12(11 \%)$ patients had normal appendices (negative appendectomy). Sahim Qusous, et al ${ }^{[16]}$ reported 68 patients $(80,9 \%)$ out of 84 patients, who underwent appendiectomy, had histopathologically proved acute appendicitis. The histopathologic results of the twelve patients with normal appendicies were: 4 children had acute mesenteric lymphadenitis, 3 females had Mittelschmerz,3 females had small ruptured right ovarian cysts, one patient had perforated chronic doudinal ulcer and one patient had no clear pathology.

\section{II .MASS versus Histopathologic Results}

Table .3 shows that 96 patients out of 110 had MASS scores $\geq 6$ and the remaining 14 patients had MASS scores $<6$. Eight patients out of these 96 patients with MASS scores $\geq 6$, had histopathologically normal appendix (negative appendectomy). Ten patients with MASS scores $<6$ had histopathologically true acute appendicitis (They scored 5). Thus, this study had sensitivity $89 \%$, specificity $33 \%$, PPV 91\%, NPV $28 \%$ and accuracy rate $83 \%$ when MASS cutoff point was 6 . These results were statistically significant, P-value was 0.04 .

Table .4 compares statistical results of this study with those of other studies when using MASS with cutoff point 6. The sensitivity of this study was comparable with sensitivities of these studies. Regarding specificity, PPV and NPV of this study results were comparable with results of some of these studies. The accuracy rate of this study was the highest when compared with those of studies above.

Table 5. Shows that 65 patients out of 110 had MASS scores $\geq 7$ while the remaining 33 patients had MASS scores $<7$. Four patients out of these 65 patients with MASS scores $\geq 7$, had histopathologically normal appendix (negative appendectomy). Thirty three patients with MASS scores $<7$ had histopathologically true acute appendicitis (They scored 5 according to MASS).Thus, this study had sensitivity $66.3 \%$, specificity $12.8 \%$, PPV $94.2 \%$, NPV $19.5 \%$ and accuracy $66 \%$ when MASS with cutoff point 7 . These results were statistically significant, P-value was 0.03 .

Table .6. compares statistical results of this study with those of other studies when MASS with cutoff point 7.The sensitivity, specificity, NPV and accuracy rate of this study are the lowest when compared with those of the studies above, but PPV of this study is high.

Acute appendicitis is a_worldwide diagnostic challenge even with the advances of surgical technology and reduction of it's mortality rate ${ }^{[21]}$. Because of occasional difficulties of preoperative diagnosis of acute appendicitis, worldwide negative appendectomy rates range from $15 \%$ to $30 \%{ }^{[12]}$. This can economically 
effect the health system. For example, 39,901 patients underwent negative appendectomies in the United States of America in 1997, which resulted in unnecessary cost of 741.5 million dollars ${ }^{[22]}$.

Alvarado Scoring System is composed of, symptoms, signs and laboratory investigations (White Blood Cell (WBC) total and differential counts). It is clinically very important tool to classify patients with suspected acute appendicitis ${ }^{[17]}$.WBC differential counting is not usually performed in many hospitals, thus Alvarado Scoring System has been modified to MASS by omitting the neutrophil count. MASS is a quick and costeffective diagnostic tool in patients suspected to complain of acute appendicitis.

Many studies reported different accuracy rates of MASS ${ }^{[6]}$. In 2008, Sun, et al. suggested that MASS with cutoff point of 6 gives a high sensitivity NPV. Also it is more appropriate than conventional cutoff point of 7

${ }^{[23]}$. Nasiri, et al ${ }^{[17]}$ recommended MASS with a cutoff point 6 that gave him sensitivity $85.1 \%$, specificity of $25 \%$, PPV 90.5\%, NPV $16.7 \%$ and accuracy rate $78.7 \%$. Regarding these findings, it appears that MASS, with cutoff point 6 , is very appropriate.

Dissimilarity of results of different studies may be due to variations of clinician experience, design of the study, size of the sample and applied statistical techniques ${ }^{[17]}$.

\section{III .Ultrasonographic Versus Histopathologic Results}

All patients enrolled in this study were ultrasonographically examined by a group of radiologists most of them were recently specified. Table 7. showes the statistical analysis of ultrasonographic results of this study. Histopathologic examination, which the gold standred, showed 98 out of 110 patients had true acute appendicitis . USG showed only 61 patients out of these 98 patients had acute appendicites (true positive ) while the remaining 37 patients had ultrasonographically normal appedicies (false negative).The remaining 12 patients had histopathologically normal appendicies, one of them had ultrasonographically acute appendicitis (false positive) while the remaining 11patients had ultrasonographically normal appedicies (true negative). Thus, USG of this study had sensitivity $62 \%$, specificity $91 \%$, PPV $98 \%$, NPV 22\% and accuracy rate $65 \%$; high spicificity and PPV but low sensitivity, NPV and accuracy rate .These results were statistically significant, P-value is 0.01 .

Table 8. Compares USG statistical results of this study with USG statistical results of other studies. The sensitivity ,NPV and accuracy rate of this study are the lowest when compared with those of the studies above ,but specificity and PPV of this study are high .USG is an operator-dependent technique ,therefore the results vary due to radiologist experience. Also variations in these USG results may be attributed to differences in design of the study, extent of sample or applied statistical analysis techniques. However, a negative USG does not exclude acute appendicitis and the clinical examination remains as a gold standred diagnostic tool.

Table 9. shows MASS with cutoff point 6, has sensitivity and accuracy rate higher than those of MASS with cutoff point of $7 \&$ USG .Also, MASS with cutoff point 6, has highest NPV (slight increase of negative appendectomy rate) but the lowest PPV (low rate of missed true acute appendicities).Thus, MASS with cutoff point 6 reduces complications of delayed diagnosis of acute appendicitis such as appendicular perforation.

Results of this study indicate that for diagnosis of acute appendicitis, using MASS with cutoff point 6 is superior to both, MASS with cutoff point 7 and USG. 


\begin{tabular}{l|l|l|l}
\hline Table .1. Modified Alvarado Scoring System (MASS ) \\
\hline Manifestations & & \multicolumn{2}{|l}{ Value } \\
\cline { 3 - 5 } & & 1 & \multicolumn{2}{l}{ yes } & \multicolumn{1}{l}{ no } \\
\hline \multirow{2}{*}{ Symptoms } & Migrating abdominal pain . & 1 & 0 \\
& Loss of appetite . & 1 & 0 \\
& Nausea and/or vomiting . & & \\
\hline Signs & RLQ abdominal tenderness . & 1 & 0 \\
& Rebound abdominal tenderness . & 1 & 0 \\
\hline $\begin{array}{l}\text { Laboratory } \\
\text { values }\end{array}$ & Fever $\geq 37.5 \mathrm{C}$. & 2 & 0 \\
\hline Total & Leukocytosis $(>10000 \mathrm{WBCs} / \mathrm{ml})$. & & \\
\hline
\end{tabular}

\begin{tabular}{l|c|c|c|l}
\hline \multicolumn{6}{l}{ Table .2. Demographic results . } \\
\hline Sex & No= & $\boldsymbol{\%}$ & Age Mean \pm SD $/$ Year & $\begin{array}{l}\text { Age range } \\
\text { /year }\end{array}$ \\
\hline Male & 67 & $60.9 \%$ & $21 \pm 8.9$ & $5-45$ \\
\hline Female & 43 & $39.1 \%$ & $27 \pm 14$ & $6-75$ \\
\hline Total & 110 & $100 \%$ & $23.3 \pm 11.9$ & $5-75$ \\
\hline
\end{tabular}

Table .3. MASS versus Histopathologic Results ( MASS with cutoff point 6 ) .

\begin{tabular}{|c|c|c|c|c|c|c|c|c|c|}
\hline \multirow{2}{*}{$\begin{array}{l}\text { Histopathologic } \\
\text { Results }\end{array}$} & \multicolumn{2}{|c|}{$\begin{array}{c}\text { MASS } \\
\text { with cutoff point } 6\end{array}$} & \multicolumn{7}{|c|}{ Statistical Analysis } \\
\hline & $\begin{array}{l}\text { Acute } \\
\text { appendicitis }\end{array}$ & $\begin{array}{l}\text { Normal } \\
\text { appendix }\end{array}$ & Total & $\begin{array}{l}\text { P- } \\
\text { Value }\end{array}$ & $\begin{array}{l}\text { Sensitivity } \\
\%\end{array}$ & $\begin{array}{l}\text { Specificity } \\
\%\end{array}$ & $\begin{array}{l}\text { PPV } \\
\%\end{array}$ & $\begin{array}{l}\text { NPV } \\
\%\end{array}$ & $\begin{array}{l}\text { Accuracy } \\
\text { Rate \% }\end{array}$ \\
\hline \multirow{2}{*}{$\begin{array}{l}\text { Acute } \\
\text { Appendicitis }\end{array}$} & True +ve & False -ve & \multirow[t]{2}{*}{98} & \multirow[t]{5}{*}{0.04} & \multirow[t]{5}{*}{89} & \multirow[t]{5}{*}{33} & \multirow[t]{5}{*}{91} & \multirow[t]{5}{*}{28} & \multirow[t]{5}{*}{83} \\
\hline & 88 & 10 & & & & & & & \\
\hline \multirow[t]{2}{*}{ Normal appendix } & False $+\mathrm{ve}$ & True -ve & \multirow[t]{2}{*}{12} & & & & & & \\
\hline & 8 & 4 & & & & & & & \\
\hline Total & 96 & 14 & 110 & & & & & & \\
\hline
\end{tabular}

\begin{tabular}{|c|c|c|c|c|c|c|c|}
\hline Study & year & no $=$ & $\begin{array}{l}\text { Sensi } \\
\text { tivity \% }\end{array}$ & $\begin{array}{l}\text { Speci } \\
\text { ficity } \%\end{array}$ & PPV \% & NPV \% & $\begin{array}{l}\text { Accuracy } \\
\text { Rate } \%\end{array}$ \\
\hline Nasiriet, et al [17] & 2012 & 75 & 85.1 & 25 & 90. & 16.7 & 78.8 \\
\hline $\begin{array}{l}\text { Caren Dsouza } \\
\text {,et al [18] }\end{array}$ & 2013 & 60 & 90 & 50 & 69 & 80 & 55 \\
\hline $\begin{array}{l}\text { Mohamed } \\
\text { Samir ,et al [3] }\end{array}$ & 2015 & 100 & 87 & 49 & 49 & 69 & 55 \\
\hline J.P.Dave1, et al [19] & 2016 & 100 & 89 & 60 & 97 & 23 & $*$ \\
\hline Our study & 2016 & 110 & 89 & 33 & 91 & 28 & 83 \\
\hline
\end{tabular}


Table .5. MASS versus Histopathologic results ( MASS with cutoff point 7 )

\begin{tabular}{|c|c|c|c|c|c|c|c|c|c|}
\hline \multirow{2}{*}{$\begin{array}{l}\text { Histopath } \\
\text { ologic } \\
\text { Results }\end{array}$} & \multicolumn{2}{|c|}{$\begin{array}{c}\text { MASS } \\
\text { with cutoff point } 7\end{array}$} & \multicolumn{7}{|c|}{ Statistical Analysis } \\
\hline & $\begin{array}{l}\text { Acute } \\
\text { appendicitis }\end{array}$ & $\begin{array}{l}\text { Normal } \\
\text { appendix }\end{array}$ & $\begin{array}{l}\text { To } \\
\text { tal }\end{array}$ & $\begin{array}{l}\text { P- } \\
\text { Value }\end{array}$ & $\begin{array}{l}\text { Sensitivity } \\
\%\end{array}$ & $\begin{array}{l}\text { Specificity } \\
\%\end{array}$ & $\begin{array}{l}\text { PPV } \\
\%\end{array}$ & $\begin{array}{l}\text { NPV } \\
\%\end{array}$ & $\begin{array}{l}\text { Accuracy } \\
\text { Rate \% }\end{array}$ \\
\hline \multirow{2}{*}{$\begin{array}{l}\text { Acute } \\
\text { Appendicitis }\end{array}$} & True +ve & False -ve & \multirow[t]{2}{*}{98} & \multirow[t]{5}{*}{0.03} & \multirow[t]{5}{*}{66.3} & \multirow[t]{5}{*}{12.8} & \multirow[t]{5}{*}{94.2} & \multirow[t]{5}{*}{19.5} & \multirow[t]{5}{*}{66} \\
\hline & 65 & 33 & & & & & & & \\
\hline \multirow[t]{2}{*}{ Normal appendix } & False +ve & True $-v e$ & \multirow[t]{2}{*}{12} & & & & & & \\
\hline & 4 & 8 & & & & & & & \\
\hline Total & 69 & 41 & 110 & & & & & & \\
\hline
\end{tabular}

\begin{tabular}{l|l|l|l|l|l|l|l}
\hline \multicolumn{1}{l}{ Table .6. Comparison between this study results and results of other studies when MASS cutoff point was } \\
\hline Study & year & no= & $\begin{array}{l}\text { Sensi } \\
\text { tivity \% }\end{array}$ & $\begin{array}{l}\text { Speci } \\
\text { ficity \% }\end{array}$ & PPV \% & NPV \% & $\begin{array}{l}\text { Accuracy } \\
\text { Rate \% }\end{array}$ \\
\hline Kanumba, et al [20] & 2011 & 127 & 94.1 & 90.4 & 95.2 & 88.4 & 92.9 \\
\hline $\begin{array}{l}\text { Caren Dsouza } \\
\text {,et al [18] }\end{array}$ & 2013 & 60 & 97 & 67 & 95 & 80 & 87 \\
\hline Mohamed Samir a ,e t al [3] & 2015 & 100 & 76 & 59 & 76 & 57 & 70 \\
\hline J.P.Dave1, et al [19] & 2016 & 100 & 72 & 83 & 98 & 16 & $*$ \\
\hline This study & 2016 & 110 & 66.3 & 12.8 & 94.2 & 19.5 & 66 \\
\hline
\end{tabular}

\begin{tabular}{|c|c|c|c|c|c|c|c|c|c|}
\hline \multirow{2}{*}{$\begin{array}{l}\text { Histopath } \\
\text { ologic } \\
\text { Results }\end{array}$} & \multicolumn{2}{|c|}{ USG Results } & \multicolumn{7}{|c|}{ Statistical Analysis } \\
\hline & $\begin{array}{l}\text { Acute } \\
\text { Appendicitis }\end{array}$ & $\begin{array}{l}\text { Normal } \\
\text { appendix }\end{array}$ & $\begin{array}{l}\text { Tot } \\
\text { al }\end{array}$ & $\begin{array}{l}\text { P- } \\
\text { Value }\end{array}$ & Sensitivity & $\begin{array}{l}\text { Specificity } \\
\%\end{array}$ & $\begin{array}{l}\text { PPV } \\
\%\end{array}$ & $\begin{array}{l}\text { NPV } \\
\%\end{array}$ & $\begin{array}{l}\text { Accuracy } \\
\text { Rate \% }\end{array}$ \\
\hline \multirow{2}{*}{$\begin{array}{l}\text { Acute } \\
\text { Appendicitis }\end{array}$} & True +ve & False -ve & \multirow[t]{2}{*}{98} & \multirow[t]{5}{*}{0.01} & \multirow[t]{5}{*}{62} & \multirow[t]{5}{*}{91} & \multirow[t]{5}{*}{98} & \multirow[t]{5}{*}{22} & \multirow[t]{5}{*}{65} \\
\hline & 61 & 37 & & & & & & & \\
\hline \multirow[t]{2}{*}{ Normal append } & False +ve & True -ve & \multirow[t]{2}{*}{12} & & & & & & \\
\hline & 1 & 11 & & & & & & & \\
\hline Total & 62 & 48 & 110 & & & & & & \\
\hline
\end{tabular}

\begin{tabular}{l|l|l|l|l|l|l|l}
\hline \multicolumn{7}{c}{ Table .8.Comparison between USG results of this study and USG results of other studies . } \\
\hline Studies & year & no $=$ & $\begin{array}{l}\text { Sensi } \\
\text { tivity } \%\end{array}$ & $\begin{array}{l}\text { Speci } \\
\text { ficity } \%\end{array}$ & PPV $\%$ & NPV \% & $\begin{array}{l}\text { Accuracy } \\
\text { Rate } \%\end{array}$ \\
\hline $\begin{array}{l}\text { SatyajeetK.S ,et al } \\
{[13]}\end{array}$ & 2014 & 55 & 84 & 50 & 80 & 57 & 71 \\
\hline $\begin{array}{l}\text { Caren Dsouza } \\
\text { et al [18] }\end{array}$ & 2013 & 60 & 92 & 89 & 97 & 66 & 85 \\
\hline $\begin{array}{l}\text { Mohamed Samir } \\
\text { et al }{ }^{[3]}\end{array}$ & 2015 & 100 & 73 & 100 & 100 & 69 & 83 \\
\hline $\begin{array}{l}\text { Peixoto RO, } \\
\text { et al [24] }\end{array}$ & 2011 & 156 & 65 & 72 & 92 & 28 & $*$ \\
\hline $\begin{array}{l}\text { Cha S-W,et al } \\
{[25]}\end{array}$ & 2014 & & 100 & 82 & 94 & 100 & $*$ \\
\hline Our study & 2016 & 110 & 62 & 91 & 98 & 22 & 65 \\
\hline
\end{tabular}




\section{CONCLUSION}

USG and MASS are both essential tools in diagnosis of acute appendicitis. MASS with a cutoff point of 6 has high sensitivity and accuracy rate. It has a slight increase in negative appendectomies but it helps in early management of acute appendicitis. MASS with a cutoff point of 6 prevents serious complications of delayed diagnosis of acute appendicitis such as appendiceal perforation .USG gives reliable results for early diagnosis of acute appendicitis but, it is an operater dependent, needing perfect training.

\section{COMPETING INTERESTS}

The four authors declare that they have no any competing interests.

\section{REFERENCES}

1. Henna E Sammalkorpi, Panu Mentula, Ari Leppäniemi. A new adult appendicitis score improves diagnostic accuracy of acute appendicitis - a prospective study. BMC Gastroenterology .2014; 14:114.

2. Chan I, Bicknell SG, Graham M. Utility and diagnostic accuracy of sonography in detecting appendicitis in a community hospital. AJR Am J Roentgenol. 2005; 184(6):1809-1812.

3. Mohamed Samir, Mohamed Hefzy, Mohamed Gaber, Khaled Moghazy . Added value of graded compression ultrasound to the Alvarado score in cases of right iliac fossa pain. African Journal of Emergency Medicine .2016.(article was in press ).

4. Abdelrahim M, Khair R, Elsiddig K O. The Validity of Alvarado Score in Diagnosis of Acute Appendicitis among Sudanese Patients. Surgery Curr Res 6: 2016; 257. doi:10.4172/21611076.1000257.

5. Velanovich V, Savata R. Balancing the normal appendectomy rate with the perforated appendicitis rate: implications for quality assurance. Am Surg .1992; 58:264-269.

6. Horzic M, Salamon A, Koplijar M, et al . Analysis of scores in diagnosis of acute appendicitis in women. Coll Anropol . 2005; 29:133.

7. Alvarado A. A practical score for the early diagnosis of acute appendicitis. Ann Emerg Med .1986; 15:557-564.

8. Jain Ravindra, Jain Anjula. A comparative study of diagnostic accuracy of clinical or other diagnostic modalities, used either alone or combined together in diagnosis of acute appendicitis. Int $J$ Biol Med Res.2015;6(2):4871-4874 .

9. Tamanna MZ, Eram U, Hussain AM, Khateeb SU, Buhary BM. Alvarado score in diagnosis of acute appendicitis. International Journal of Basic and Applied Medical Sciences .2012; 2(1):66-70 .

10. Raja Shekar Jade, Uday Muddebihal M, Naveen N. Modified alvarado score and its application in the diagnosis of acute appendicitis. International Journal of Contemporary Medical Research .2016;3(5):1398-1400.

11. Ramachandra J, Sudhir M, Sathyanarayana B.A. Evaluation Of Modified Alvarado Score In Preoperative Diagnosis Of Acute Appendicitis. Journal of Evolution of Medical and Dental Sciences. 2013November 18; Volume (2)/ Issue (46) :9019-29 .

12. Patel V, Kela M, Prasad S, Gautam AS, Gupta M. Evaluation of modified Alvarado scoring system in diagnosis of acute appendicitis - a prospective study. Int Surg J .2016;3:621-5 .

13. Satyajeet Kumar Singh, Kunal, Chitrangada . Comparative Study of Diagnostic Accuracy of Modified Alvarado Score and Ultrasonography in Acute Appendicitis . IOSR Journal of Dental and Medical Sciences (IOSR-JDMS) V 13, Iss 1 Ver. VII. (Jan 2014), PP 36-40 www.iosrjournals.org

14. Leann E. Linam, Martha Munden . Sonography as the First Line of Evaluation in Children With Suspected Acute Appendicitis. J Ultrasound Med .2012; 31:1153-1157 |0278-4297| www.aium.org. 
15. Sayani R, Mustahsan SM, Ali AAM, Anwar M . Role of focused Ultrasound in the diagnosis of acute appendicitis in Pediatric population.Selection of a standard diagnostic criterion . International Journal of Endorsing Health Science Research .2015 March; Volume 3 Issue 1:29-31 .

16. Sahim Qusous, Ala Odeh, Sahel Haddadin ,et al. Correlation between Surgical Alvarado score and histological examination in the assessment of acute appendicitis . Int J Med Invest .2015; vol 5; num 1:1-4.

17. Nasiri et al. Diagnostic values of ultrasound and the Modified Alvarado Scoring System in acute appendicitis. International Journal of Emergency Medicine .2012;5:26 .

18. Caren Dsouza, John Martis, Vinay Vaidyanathan . Diagnostic Efficacy Of Modified Alvarado Score Over Graded Compression Ultrasonography. Nitte University Journal of Health Science. 2013 September; Vol. 3, No.3:105-8 .

19. J.P.Dave1, P.K. Dharaviaparmar, G.N. Vaghasiya, M.Vekariya4, S.O.Sankhala. Study of Modified Alvarado Scoring System As A Diagnostic Tool For Acute Appendicitis . Int J Res Med. 2016; 5(1);25-27 .

20. Emmanuel S Kanumba, Joseph B Mabula, Peter Rambau, Phillipo L Chalya. Modified Alvarado Scoring System as a diagnostic tool for Acute Appendicitis at Bugando Medical Centre, Mwanza, Tanzania . BMC Surgery . 2011; 11:4 .

21. Denizbasi A, Unluer EE. The role of the emergency medicine resident using the Alvarado score in the diagnosis of acute appendicitis compared with the general surgery resident. Eur J Emerg Med .2003; 10(4):296-301.

22. Old JL, Dusing RW, Yap W, Dirks J. Imaging for suspected appendicitis. Am Fam Physician .2005 Jan 1; 71(1):71-78.

23. Sun J, Noh HW, Min YG, et al . Receiver operating characteristic analysis of the diagnostic performance of a computed tomographic examination and the alvarado score for diagnosing acute appendicitis: emphasis on age and sex of the patients. J Comput Assist Tomogr 2008, 32(3):386391.

24. Peixoto RO, Nunes TA, Gomes CA. Diagnostic rates of abdominal ultrasonography in acute appendicitis. Influence of gender, physical constitution, disease time evolution and experience of radiologist. Rev Col Bras Cir. [periódico na Internet] 2011; 38(2). Disponível em URL: http://www.scielo.br/rcbc .

25. Cha S-W, Kim IY, Kim YW .2014 Quantitative Measurement of Elasticity of the Appendix Using Shear Wave Elastography in Patients with Suspected Acute Appendicitis. PLoS ONE 9(7): e101292. doi:10.1371/journal.phone.0101292. 